\title{
Overshooting of clean tropospheric air in the tropical lower stratosphere as seen by the CALIPSO lidar
}

\author{
J.-P. Vernier ${ }^{1,2}$, J.-P. Pommereau ${ }^{2}$, L. W. Thomason ${ }^{1}$, J. Pelon ${ }^{2}$, A. Garnier ${ }^{2}$, T. Deshler ${ }^{3}$, J. Jumelet ${ }^{2}$, and \\ J. K. Nielsen ${ }^{4}$ \\ ${ }^{1}$ NASA Langley Research Center, Hampton, VA 23666, USA \\ ${ }^{2}$ LATMOS, CNRS-INSU, UMR8190, Université de Versailles St. Quentin, Université de Paris 6, France \\ ${ }^{3}$ Department of Atmospheric Science, University of Wyoming, USA \\ ${ }^{4}$ Danish Meteorological Institute, Copenhagen, 2100, Denmark
}

Received: 12 August 2010 - Published in Atmos. Chem. Phys. Discuss.: 6 January 2011

Revised: 18 May 2011 - Accepted: 3 September 2011 - Published: 20 September 2011

\begin{abstract}
The evolution of aerosols in the tropical upper troposphere/lower stratosphere between June 2006 and October 2009 is examined using the observations of the space borne CALIOP lidar aboard the CALIPSO satellite. Superimposed on several volcanic plumes and soot from an extreme biomass-burning event in 2009, the measurements reveal the existence of fast-cleansing episodes in the lower stratosphere to altitudes as high as $20 \mathrm{~km}$. The cleansing of the layer, which extends from 14 to $20 \mathrm{~km}$, takes place within 1 to 4 months during the southern tropics convective season that transports aerosol-poor tropospheric air into the lower stratosphere. In contrast, the convective season of the Northern Hemisphere summer shows an increase in the particle load at the tropopause consistent with a lofting of air rich with aerosols. These aerosols can consist of surface-derived material such as mineral dust and soot as well as liquid sulfate and organic particles. The flux of tropospheric air during the Southern Hemisphere convective season derived from CALIOP observations is shown to be 5 times at $16 \mathrm{~km}$ and 20 times at $19 \mathrm{~km}$ larger, respectively, than that associated with flux caused by slow ascent through radiative heating. These results suggest that convective overshooting is a major contributor to troposphere-to-stratosphere transport with concomitant implications for the Tropical Tropopause Layer top height, the humidity, the photochemistry and the thermal structure of the layer.
\end{abstract}

Correspondence to: J.-P. Vernier (jeanpaul.vernier@nasa.gov)

\section{Introduction}

Most natural and human-made short- and long-lived trace gases controlling stratospheric chemistry and radiative balance are emitted at the surface and rapidly lifted up in the tropics by convective systems. They reach the maximum outflow of convective systems near $14 \mathrm{~km}$ within a few hours (Gettelman and Forster, 2002), from where they are transported upward across the Tropical Tropopause Layer (TTL) into the stratosphere and distributed globally by the BrewerDobson circulation (Holton et al., 1995). Two mechanisms contribute to the transport across the TTL: a slow ascent on a time scale of 6 to 9 months up to $20 \mathrm{~km}$ by radiative heating of air masses (Holton, 1995; Corti et al., 2005; Yang et al., 2008; Fueglistaler et al., 2008) and fast convective overshooting updrafts above land thunderstorms as proposed by Danielsen $(1982,1993)$. Convection associated with the Asian monsoon during the Northern Hemisphere summer may also contribute to the latter mechanism bypassing tropical areas (Dunkerton, 1995; Gettelman et al., 2004; Randel et al., 2010; Fu et al., 2006).

Due to the time required to ascend through the TTL by slow radiative heating, very short-lived chemically active species should be deactivated and the air is expected to be dehydrated at the cold point tropopause. Although recognized to occur episodically (Danielsen, 1982, 1993), fast convective overshooting of adiabatically cooled air is generally believed to occur too infrequently to be significant in the overall mass flux (Fueglistaler et al., 2008 and references therein). However, recent observations adjacent to or above continental tropical convective systems during recent European balloon and high altitude aircraft campaigns,

Published by Copernicus Publications on behalf of the European Geosciences Union. 
HIBISCUS (Pommereau et al., 2011) and TROCCINOX (Chaboureau et al., 2007) in Brazil, SCOUT-O3 in northern Australia (Brunner et al., 2009) and SCOUT-AMMA in West Africa (Cairo et al., 2010), have shown that convective overshoots are more common than previously thought. They can reach altitudes as high as $19 \mathrm{~km}$ and thus strongly impact the thermal structure of the TTL (Pommereau et al., 2011; Cairo et al., 2010). Moreover, during these field campaigns, the air was not found to be dehydrated as often assumed, but instead associated with water vapor enhancements after evaporation of the injected ice crystals (Nielsen et al., 2007; Chaboureau et al., 2007; Corti et al., 2008; Khaykin et al., 2009), a process relatively well captured by cloud resolving models (CRM) (Jensen et al., 2007; Chaboureau et al., 2007; Grosvenor et al., 2007).

Although the frequent occurrence of such events over tropical continents is becoming more widely accepted, their contribution to troposphere-to-stratosphere transport at global scale is still debated. There are indications however that it might be more significant than previously thought. For instance, the Tropical Rainfall Measurements MissionPrecipitation Radar (TRMM-PR) indicates that at least $1 \%$ of storm turrets reach the TTL (Liu and Zipser, 2005), particularly over Africa (Zipser et al., 2006; Liu and Zipser 2009). Since TRMM-PR are only sensitive to large hydrometeors produced in the core of deep convective systems, this percentage could be significantly underestimated.

Trace gases measurements in the UT/LS such as $\mathrm{CH}_{4}$ concentration from HALOE, $\mathrm{N}_{2} \mathrm{O}$ from ODIN-SMR, $\mathrm{N}_{2} \mathrm{O}$ and CO from AURA-MLS, show maxima in the lower stratosphere over tropical continents (Ricaud et al., 2007; Schoeberl et al., 2006), indicative of fast vertical transport over these areas. Finally, the high-resolution aerosols profiles of the CALIOP lidar observations show an apparent aerosol cleansing of the TTL and lower stratosphere during the Northern Hemisphere winter that may be linked to convective overshooting (Vernier et al., 2009).

Except for infrequent strong volcanic eruptions (McCormick et al., 1995), the sources of aerosols in the tropical Upper Troposphere and Lower Stratosphere are poorly understood. In situ particle measurements have shown that the production of Aitken nuclei $(r<50 \mathrm{~nm})$ is very high in the tropics compared to the mid-latitudes due to gas-toparticles conversion of $\mathrm{SO}_{2}$ and other gas precursors (e.g. DMS) (Brock et al., 1995). High altitude aircraft particle composition and volatility measurements have indicated the presence of aerosols, largely made of a sulfate-organic mixture, and, to a smaller extent, black carbon and other carbonaceous materials (Froyd et al., 2009; Spackman et al., 2011; Bormann et al., 2010). But CALIPSO and SAGE II have also demonstrated that even small volcanic eruptions contribute significantly to the sulfate load of the tropical lower stratosphere (Vernier et al., 2011b). The lifetime of aerosols in the upper troposphere is controlled by convection by which they can be removed and precipitated to the ground (i.e. "washout"). Since at least $1 \%$ of tropical convective systems reach the TTL (Liu and Zipser, 2005), the process might be an important sink of aerosols below the tropopause in this region (Hamill et al., 1997).

The objective of this paper is to further examine the CALIOP clean air events from the beginning of the mission in June 2006 until October 2009, and their possible relation with convection in the tropics. Section 2 provides a description of CALIOP aerosols observations in the UT/LS, followed in Sect. 3 by a comprehensive analysis of the vertical and latitudinal clean air propagation during the Northern Hemisphere (NH) fall-winter-spring in 2007-2008. This period is the optimum period as it is least affected by volcanic or fire events of any period in the CALIOP record. The origin of the clean air is investigated in Sect. 4. Section 5 provides an estimate of tropospheric air mass fluxes at the global scale derived from the observed cleansing compared to the contribution of slow ascent by radiative heating, and Sect. 6 discusses alternative microphysical and dynamical processes which could also contribute to the observations. The conclusions are summarized in Sect. 7.

\section{Cleansing of the UT/LS as seen by CALIOP}

The CALIPSO mission, a collaboration between the National Aeronautics and Space Administration (NASA) and the Centre National d'Etudes Spatiales (CNES), is dedicated to the study of clouds and aerosols from the troposphere to the stratosphere (Winker et al., 2010). As a part of the A-Train constellation, the satellite is in polar orbit at $705 \mathrm{~km}$, providing measurements at 01:30 and 13:30 LT with a repeat cycle of 16 days. Since June 2006, the CALIOP lidar measures backscatter profiles at $532 \mathrm{~nm}$ and $1064 \mathrm{~nm}$, and depolarization at $532 \mathrm{~nm}$ with a vertical resolution of around $200 \mathrm{~m}$ in the stratosphere (Hostetler et al., 2006). Because of the low signal-to-noise ratio on individual profiles, the detection of aerosols in the stratosphere requires averaging. A method for deriving the Scattering Ratio (SR) (Eq. 1) has been developed by Vernier et al. (2009). The procedure is based on averaging $532 \mathrm{~nm}$ nighttime-only measurements in one degree latitude bands ( $\sim 300$ profiles) and further arranged into a regular grid of $1^{\circ}$ latitude $\times 2^{\circ}$ longitude and $200 \mathrm{~m}$ in altitude for the CALIPSO 16-day repeat cycle. To rectify a known CALIOP calibration deficiency that is particularly important in the UT/LS, all data are corrected using the recalibration technique described in Vernier et al. (2009). Artifacts in the CALIOP SR time series created by sudden changes in the GEOS-5 temperature at $36-39 \mathrm{~km}$, the aerosol free altitude layer used for adjusting the calibration, have been removed by replacing the GEOS- 5 temperatures with those of the ECMWF ERA-INTERIM reanalysis found to better match the temperatures observed by MLS/Aura (Schwartz et al., 2008). In addition, a mask for the South Atlantic Anomaly (SAA) has been applied with which all $532 \mathrm{~nm}$ 
profiles showing dark noise greater than 100 photons in this area have been discarded (Hunt et al., 2009). Finally, clouds below $20 \mathrm{~km}$ have been filtered on the same grid by removing all pixels for which the mean volume depolarization ratio $(\delta)$ is greater than $5 \%$ using Eq. (2).

$\mathrm{SR}=\frac{\beta_{\mathrm{part}}+\beta_{\mathrm{mol}}}{\beta_{\mathrm{mol}}}$

$\delta=\frac{\beta_{/ /}+\beta_{\perp}}{\beta_{\perp}}$

where $\beta_{\mathrm{mol}}$ and $\beta_{\mathrm{part}}$ represent the molecular and particulate backscatter (note that the sum of both corresponds to the total backscatter as reported by the CALIOP lidar). $\beta_{\perp}$ is the perpendicular backscatter at $532 \mathrm{~nm}$ measured by CALIOP which is sensitive to aspherical particles such as ice crystals. $\beta_{/ /}$is the parallel backscatter at $532 \mathrm{~nm}$.

Shown in Fig. 1 is the resulting evolution of the CALIOP zonal mean SR between $14-30 \mathrm{~km}$ within the $20^{\circ} \mathrm{N}-20^{\circ} \mathrm{S}$ tropical band (after removing the SAA) from the beginning of the mission in June 2006 until October 2009. This is complemented by Fig. 2, which represents the time/latitude cross sections of the same quantity at four potential temperature levels: $380 \mathrm{~K}(17 \mathrm{~km}), 420 \mathrm{~K}(18.5 \mathrm{~km}), 460 \mathrm{~K}(20 \mathrm{~km})$ and $500 \mathrm{~K}(21.5 \mathrm{~km})$. The blank section in February-March 2009 on both figures is due to an interruption of the CALIOP measurements.

Several volcanic events with a Volcanic Explosivity Index (VEI) of 4, listed in Table 1, can be seen in the tropics in Fig.1 as well as at mid-latitudes (Fig. 2) with SR values greater than 1.2. The largest feature is associated with the eruption of the Soufriere Hills volcano (index 1 in Figs. 1 and 2) on Montserrat Island in the Caribbean on 20 May 2006. The plume remained in the tropics at $18-20 \mathrm{~km}(460 \mathrm{~K})$ for $4-5$ months before starting to ascend into the tropical stratosphere eventually reaching $25 \mathrm{~km}$ more than a year later. A second volcanic feature, less intense, is seen in October-December 2006 after the eruption of the Tavurvur (2) cone of the Rabaul volcano in Papua-New Guinea on 7 October. The lifetime of this plume is much shorter than the first one as it is rapidly transported to mid-latitudes at isentropic levels from 360 to $440 \mathrm{~K}$ (Fig. 2) and replaced by air of low aerosol concentration in the tropics. Other volcanic plumes can be seen during the summers 2008 and 2009 in the Northern Hemisphere (NH) after the eruption of Kasatochi (5) in Alaska (US) on 7 August 2008 (Bourassa et al., 2010) and Sarychev (7) in Kamchatka (Russia) on 12 June 2009. Both plumes are further transported to the northern tropics, but more rapidly at lower $(380 \mathrm{~K})$ than at higher levels $(460 \mathrm{~K})$ (Fig. 2), creating an apparent ascent in the tropics (Fig. 1). The remaining feature seen at $480-520 \mathrm{~K}(21 \mathrm{~km})$ in March-April 2009 after the data gap (Figs. 1 and 2), with a SR between 1.10-1.20, is not the signature of a volcano but of soot particles (6) from an extreme biomass-burning episode near Melbourne in Victoria (southern Australia) on 7 February 2009 (Trepte et al., 2009).

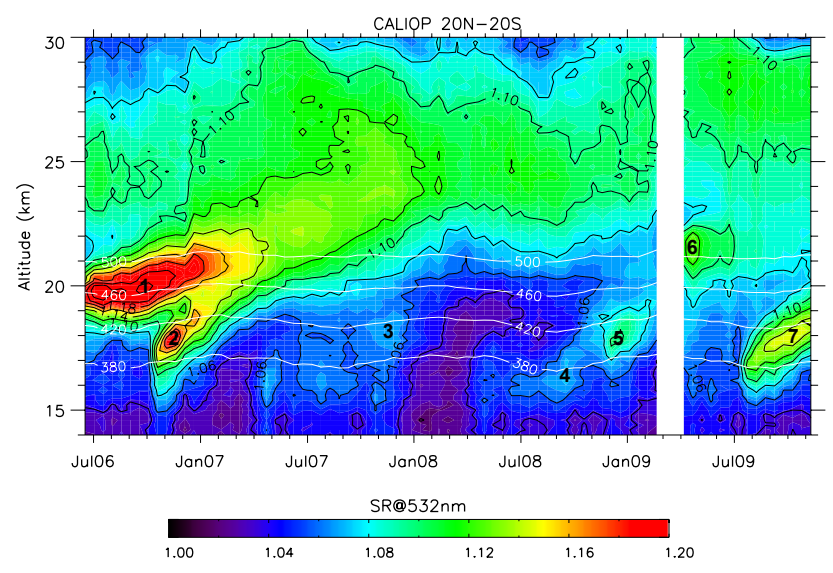

Fig. 1. Mean CALIOP Scattering Ratio (SR) (contour steps 0.02) between $14-30 \mathrm{~km}$ and $20^{\circ} \mathrm{S}-20^{\circ} \mathrm{N}$ from June 2006 to October 2009 after removing cloudy pixels of depolarization ratio at $532 \mathrm{~nm}$ greater than $5 \%$. The precision of the SR profiles is $2 \%$, the vertical resolution $200 \mathrm{~m}$ and the time resolution 16 days. Shown by white lines are temperature potential levels at 380, 420, 460 and $500 \mathrm{~K}$. Each identified plume is indexed and listed in Table 1.

Table 1. List of volcanic eruptions with their corresponding Volcanic Explosivity Index (VEI) or fires that have produced a plume detected by CALIPSO during the 2006-2009 period.

\begin{tabular}{llll}
\hline Volcano/Fire & Date & Latitude & VEI \\
\hline Soufrière Hills (1) & 20-May-06 & $16^{\circ} \mathrm{N}$ & $4 ?$ \\
Tavurvur (2) & 7-Oct-06 & $4^{\circ} \mathrm{S}$ & $4 ?$ \\
Jebel Al-Tair (3) & 30-Sep-07 & $15^{\circ} \mathrm{N}$ & $4 ?$ \\
Okmok (4) & 12-Jul-08 & $55^{\circ} \mathrm{N}$ & 4 \\
Kasatochi (5) & 7-Aug-08 & $55^{\circ} \mathrm{N}$ & 4 \\
Fire/Victoria (6) & 7-Feb-09 & $37^{\circ} \mathrm{S}$ & \\
Sarychev (7) & 12-Jun-09 & $48^{\circ} \mathrm{N}$ & $4 ?$ \\
\hline
\end{tabular}

In addition to these events, aerosol layers (index $\mathrm{M}$ in Fig. 2) are also present at 360-400 K from June to September, more intense in the Northern Hemisphere subtropics and at mid-latitudes, when no volcanic events could be identified in 2006 and 2008. These aerosol layers appear every year during the Asian monsoon period, extending from Western Asia to Eastern Mediterranean (Vernier et al., 2011a). The monthly mean latitude-height cross-sections between June and September in 2007 over Asia (not shown), indicates that they do not come from an old volcanic plume transported southward across the weak barrier afforded by the NH summer jet stream (Chen, 1995; Dunkerton, 1995), but rather from the deep convective outflow of the Asian monsoon.

Besides those features, the "clean air" events are particularly noteworthy. These events have a scattering ratio less than 1.04 that form near the base of the TTL $(\sim 14 \mathrm{~km})$ and propagate rapidly upward. Since the CALIOP lidar at $532 \mathrm{~nm}$ 


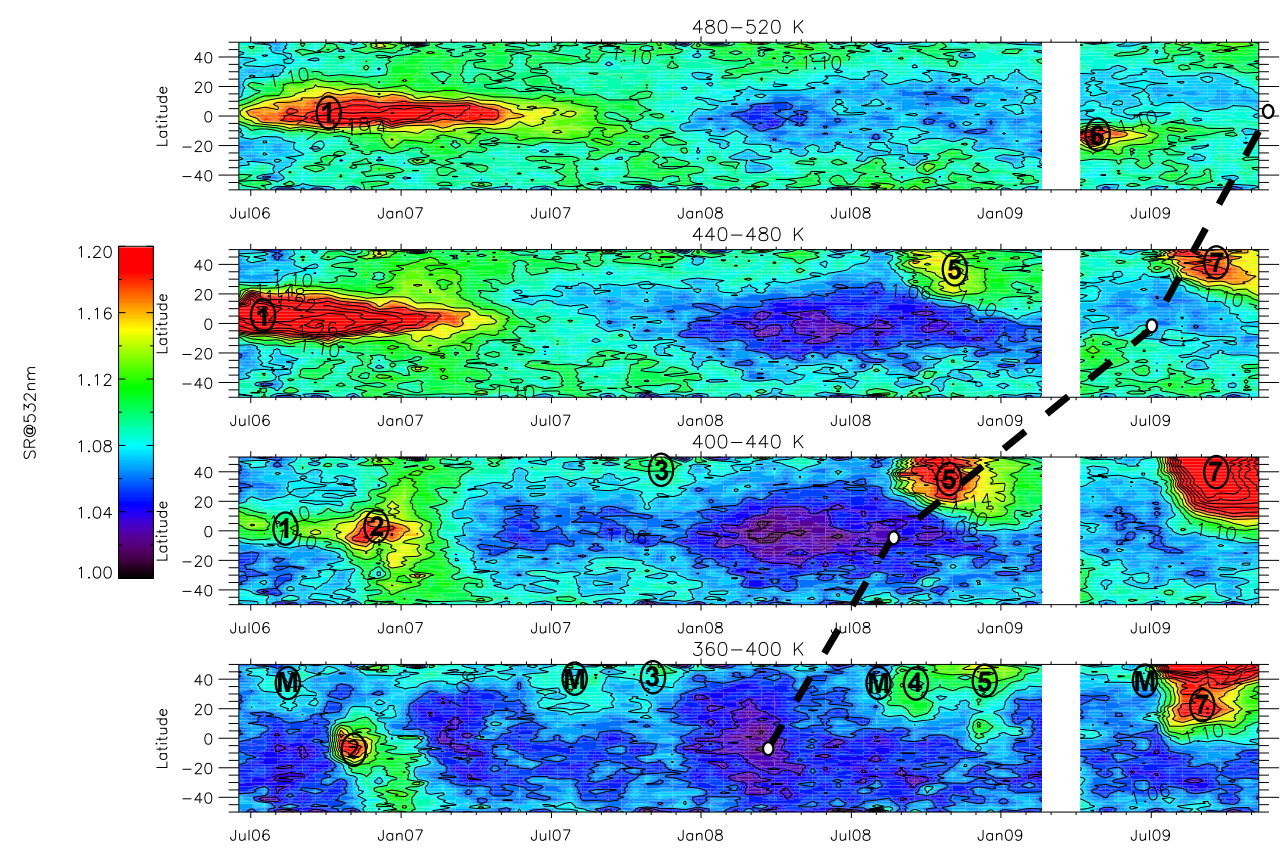

Fig. 2. Latitude-time cross-sections of CALIOP SR within $40 \mathrm{~K}(1.5 \mathrm{~km})$ thick layers centred at $380 \mathrm{~K}(17 \mathrm{~km}), 420 \mathrm{~K}(18.5 \mathrm{~km}), 460 \mathrm{~K}$ $(20 \mathrm{~km})$ and $500 \mathrm{~K}(21.5 \mathrm{~km})$ from June 2006 until October 2009. The black dotted curve shows the timing of the uplift of clean air if it was due to slow ascent by radiative heating as calculated by Yang et al. (2008). Letter M corresponds to the aerosol feature associated with the Asian monsoon.

is primarily sensitive to particles with radii larger than $30 \mathrm{~nm}$, a "clean air" event refers to air masses with low densities of such particles. The first event in early 2007 can be seen from 14 to $18 \mathrm{~km}(360-440 \mathrm{~K})$, more pronounced in the tropics and that rapidly replaced the Tavurvur plume. A similar episode occurred during the same season in 2008, a year undisturbed by volcanoes and fires, the lower stratosphere being cleansed up to $19-20 \mathrm{~km}$ and remained relatively aerosol-free until the following year between 18 and $21 \mathrm{~km}(440-520 \mathrm{~K})$. The vertical propagation of the clean air during the NH winter 20072008 is compared in Fig. 2 to the theoretical ascent of the lowest bulb of clean air from $380 \mathrm{~K}$ to $500 \mathrm{~K}$ using Yang et al. (2008) estimations. The observed propagation is much more rapid than the one deduced from the radiative ascent model.

Though of higher resolution and free of clouds interference in the CALIOP data, the cleansing of the lower stratosphere during the $\mathrm{NH}$ winter-spring, resulting in an aerosol annual cycle, was observed by SAGE II at $18 \mathrm{~km}$ between 1998-2005 (Thomason et al., 2008). It is also confirmed by independent balloon measurements in the tropics within the SCOUT-O3 project shown in Fig. 3 displaying: (i) the SR derived from the particle size distribution of an optical particle counter (OPC, Deshler et al., 2003) during a flight in May 2008 from Teresina in Brazil at $5^{\circ} \mathrm{S}$, (ii) the mean SR profile measured by backscattersondes (BKS, Rosen and Kjome, 1991) flown in September 2008 at $12^{\circ} \mathrm{N}$ in Niamey, Niger. Both are compared to the mean CALIOP SR within a box of
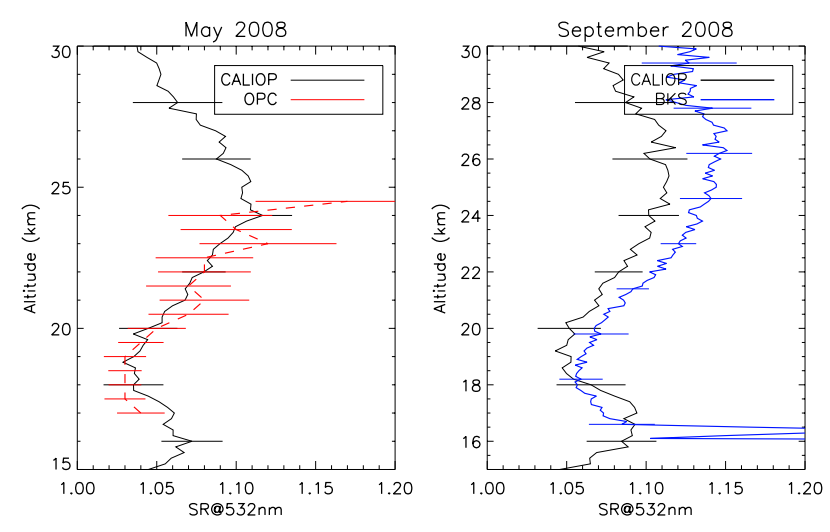

Fig. 3. Left: SR (red) derived from the aerosol size distribution of a balloon-borne Optical Particle Counter at $5^{\circ} \mathrm{S}$ in Brazil in May 2008; right: mean scattering ratio reported by BKS sondes at $12^{\circ} \mathrm{N}$ in Niger in September 2008; both compared to CALIOP SR within a box of $\pm 7^{\circ}$ latitude $\pm 70^{\circ}$ longitude centred at the location of the balloon flight.

$\pm 7^{\circ}$ latitude $\pm 70^{\circ}$ longitude centered at the respective balloon locations. Both balloon data show a drop of SR between 17 and $20 \mathrm{~km}$ consistent with that reported by CALIOP. The peaks below $17 \mathrm{~km}$ in the BKS profile are due to the presence of high altitude clouds that are discarded in the CALIOP analysis. The aerosol enhancement observed by CALIOP at and below $17 \mathrm{~km}$ in September 2008 is due to the debris of 

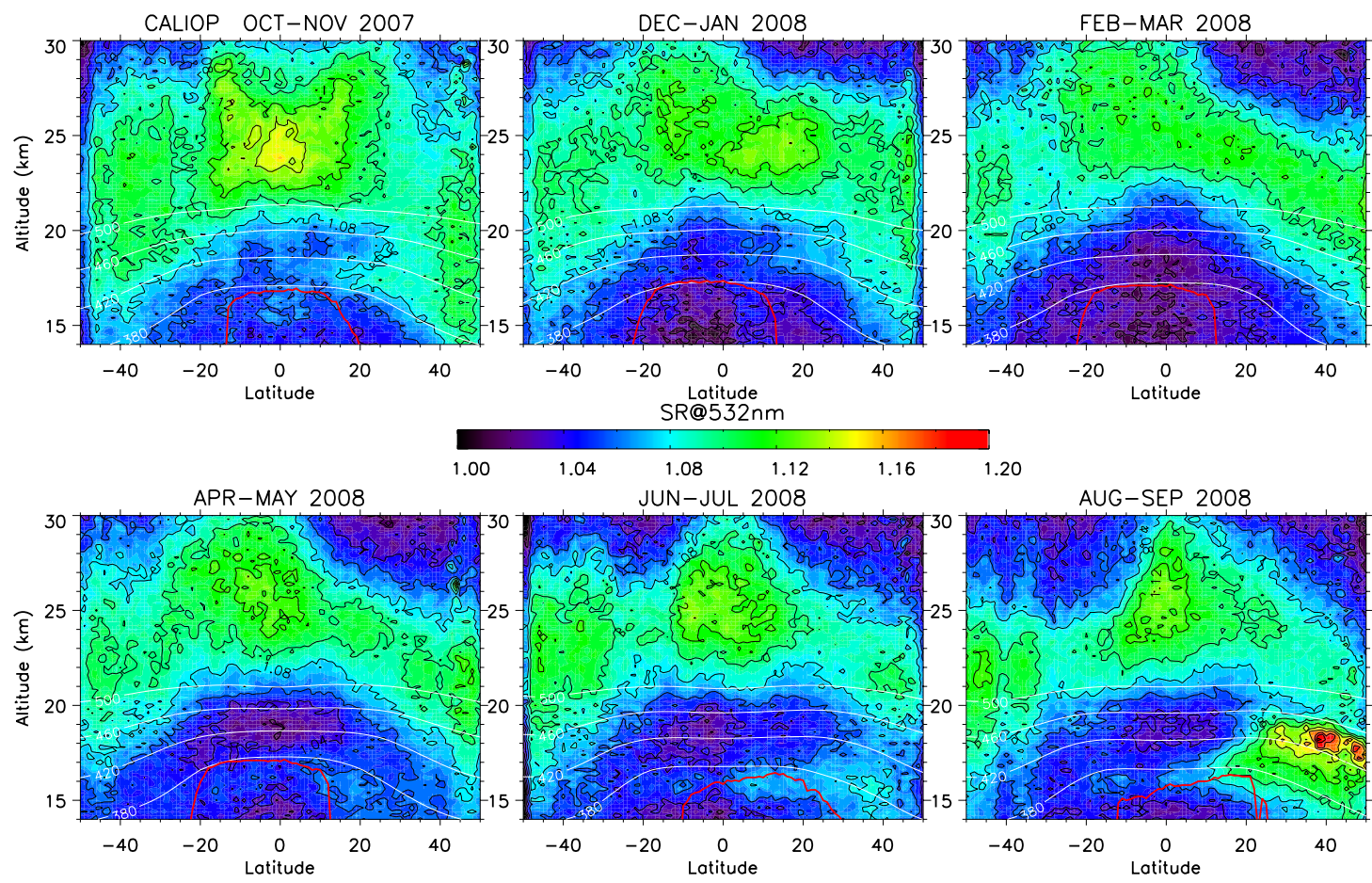

Fig. 4. Latitude-height cross-sections of mean CALIOP SR from September 2007 to August 2008 every two months. Shown by white lines are temperature potential levels at $380,420,460$ and $500 \mathrm{~K}$ and by red lines the mean cloud top height (zonal mean depolarization ratio $=$ $5 \%)$.

the Alaskan volcano in the northern part of the $\pm 7^{\circ}$ latitude box (at 360-400 K in Fig. 2).

Features such as volcanic or soot plumes are observed in the tropical and extra tropical UT/LS during the first 40 months of the CALIPSO mission providing unprecedented insight into their vertical and meridional transport. The Soufriere Hills plume is slowly transported in the middle stratosphere at an average velocity of $300 \mathrm{~m} \mathrm{months}^{-1}$ by the Brewer-Dobson circulation and displays features similar to that of the well known water vapor tape recorder (Rosenlof et al., 1995; Mote et al., 1996). The meridional transport of the plume in or out of the tropics is shown to depend on the altitude, faster at lower levels and becoming gradually inhibited at increasing altitude until reaching the tropical pipe (Plumb, 1996). This is consistent with the drop of ozone variability at this level reported using circumnavigating longduration balloon measurements by Borchi et al. (2007). On the other hand, the volcanic plumes in the TTL and tropical lower stratosphere are shown to disappear more quickly than expected based solely on meridional transport but are also influenced by clean air episodes especially pronounced between $20^{\circ} \mathrm{S}-10^{\circ} \mathrm{N}$ during the Northern Hemisphere Winter at $14-20 \mathrm{~km}$ (Figs. 1 and 2). The only period undisturbed by additional aerosol input is the $2008 \mathrm{NH}$ winter during which the clean air is observed to propagate rapidly in the TTL and lower stratosphere up to $19-20 \mathrm{~km}$.

\section{Location and vertical propagation of the cleansing}

Since the low signal-to-noise ratio of CALIOP does not allow constructing SR maps between 15 and $20 \mathrm{~km}$ with a temporal resolution of less than 2 months, and the Quasi Biennal Oscillation $(\mathrm{QBO})$ was in its easterly phase during the winter 2008 with zonal wind speed of around $-15 \mathrm{~m} \mathrm{~s}^{-1}$ at $50 \mathrm{hPa}$ (www.cpc.noaa.gov/data/indices/qbo.u50.index), an air mass in the tropical lower stratosphere was circumnavigating twice during this two-month period, making it difficult to determine a possible longitudinal dependence of the cleansing.

We then choose to look at two-month cross-sections shown in Fig. 2 for October 2007 through September 2008 annotated with the mean zonal cloud top in red in Fig. 4. The zonal cloud top is determined using the mean zonal depolarization ratio $(\delta)$, derived from the statistics of cloudy/aerosols pixels separation as described in Sect. 2 . From this figure, it can be seen that the cleansing of the UTLS starts in October/November 2007 and continues in December/January with SR values falling below 1.04 between $14 \mathrm{~km}$ to $17 \mathrm{~km}$. The low aerosol region propagates between $20^{\circ} \mathrm{S}-5^{\circ} \mathrm{N}$ in phase with the latitude of cloud tops. The cleanest period occurs in February-March where low SR values reach altitudes as high as $20 \mathrm{~km}, 2-3 \mathrm{~km}$ higher than cloud tops, making the whole TTL and the lower stratosphere virtually free of aerosol. Later in April-May, an isolated 


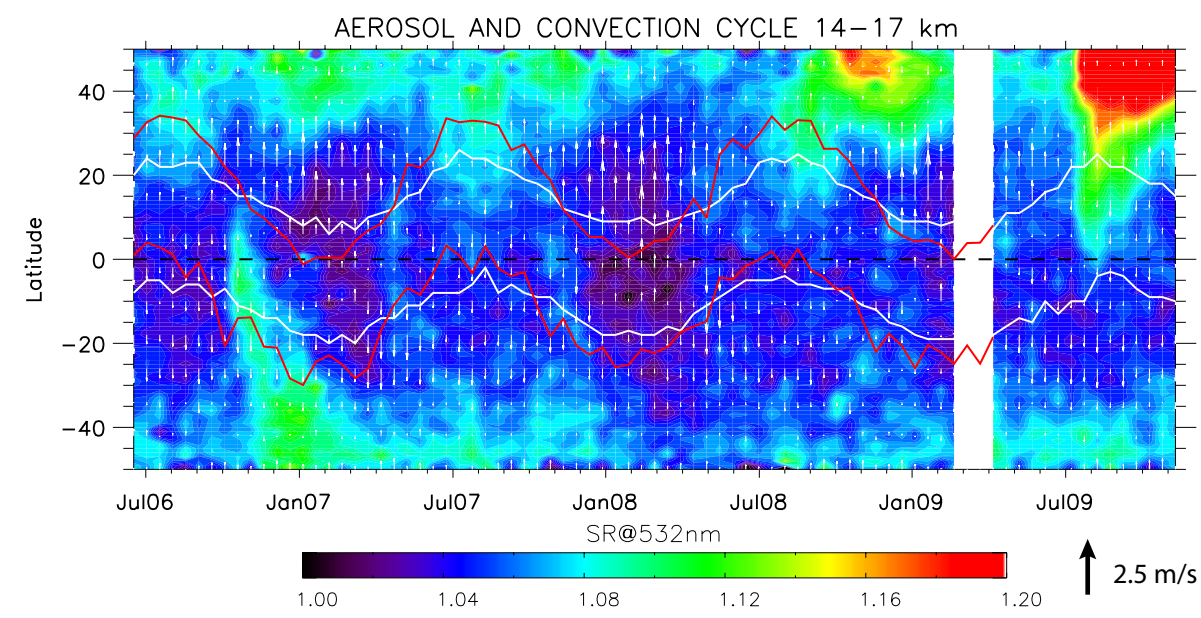

Fig. 5. Evolution of the mean SR between $14-17 \mathrm{~km}$ from CALIPSO. Superimposed are, in red, the mean ITCZ latitudinal location as revealed by the 10th and 90th percentile frequency of MCS and in white, that of cirrus clouds, given respectively by the TRMM PR and CALIPSO. The cloudy pixel from CALIPSO are determined using the depolarization ratio channel. The white arrows represent the mean meridionnal component of ECMWF wind field every 16 days.

bulb of clean air is seen at $18-20 \mathrm{~km}$ between $10^{\circ} \mathrm{N}-20^{\circ} \mathrm{S}$ above cloud tops, which remains at this level until September 2008. Also seen in April-May is the presence of an aerosol layer at $16-17 \mathrm{~km}$, between $10-30^{\circ} \mathrm{N}$, reinforced and extended to higher latitude in June-July, before the arrival of the Kasatochi plume.

To shed light on the relationship between cleansing episodes and deep convection, Fig. 5 shows the latitudinal evolution of the SR between $14-17 \mathrm{~km}$ together with the location of the Inter Tropical Convergence Zone (ITCZ) at $14 \mathrm{~km}$ as inferred from the TRMM Mesoscale Convective Systems (MCS) position (red) and the CALIPSO cloud cover (white). White arrows show the mean meridional wind every 16 days derived from ECMWF at $100 \mathrm{hPa}$. The TRMM MCSs are selected by considering contiguous precipitating areas greater than $2000 \mathrm{~km}^{2}$ of radar signal larger than $20 \mathrm{dBZ}$ reaching at least $14 \mathrm{~km}$, with a minimum of 2 flashes as observed by the Lightning Imaging Sensor (LIS) also on TRMM. The flash discrimination is chosen to select only MCSs with strong updrafts inducing hail formation and lightning. All MCSs are extracted with those four conditions from the TRMM database (http://trmm.chpc.utah.edu/) from June 2006 to February 2009 and sorted into 16-day bins comparable to CALIPSO. The limits of the ITCZ (red line) from these observations are derived using the 10th and 90th percentile of latitudinal position of MCSs. The CALIPSO cloud area is derived from the depolarization channel as described above (Fig. 4). As above, the bounds of clouds are defined by the 10th and 90th percentile latitudinal location of cloudy pixels. The term "cloudy pixels" represents all types of clouds observed by CALIPSO including storms, anvils and cirrus. During the NH winter, the clouds extend to higher latitude than the ITCZ defined by the MCSs location likely due to the persistent thick cirrus cloud layer up to $10^{\circ} \mathrm{N}$ in the West Pacific where the tropopause is the highest and coldest (Sassen et al., 2009). In contrast, the ITCZ area extends to higher latitudes than the clouds at $14-17 \mathrm{~km}$ in the summer of both hemispheres and particularly in the North. This is likely due to the less frequent clouds during CALIPSO overpasses at 01:40 a.m. and p.m. over land convective regions (monsoon in the north) whereas cloud cover exhibits a large diurnal cycle with a strong maximum around 16:00-17:00 $\mathrm{h}$ local (Liu and Zipser, 2005).

Aside from volcanic plumes during the NH winter 2006 (Tavurvur, $0-20^{\circ} \mathrm{S}$ ) and the NH summers of 2008 and 2009 (Kasatochi, Sarychev, $20-50^{\circ} \mathrm{N}$ ), the aerosols in the TTL show an annual cycle. The maximum cleansing of the 14$17 \mathrm{~km}$ layer is located in the middle of the ITCZ area in the Southern Hemisphere $\left(5^{\circ} \mathrm{S}-25^{\circ} \mathrm{S}\right)$ during the northern winter but extends further north and south than the limits of the ITCZ area. As shown by the meridional wind arrows, this altitude level corresponds to the upper branch of the trade wind Hadley cell which is associated with the advection of airmasses from the ITCZ to the subtropics where there is no more convection. In contrast, it is the opposite in the Northern Hemisphere summer, where a maximum aerosols load is observed between $20-40^{\circ} \mathrm{N}$ in the northern part of the ITCZ area. Thus, the impact of convection on the TTL aerosols load may depends on the amount of aerosols available at the surface. 


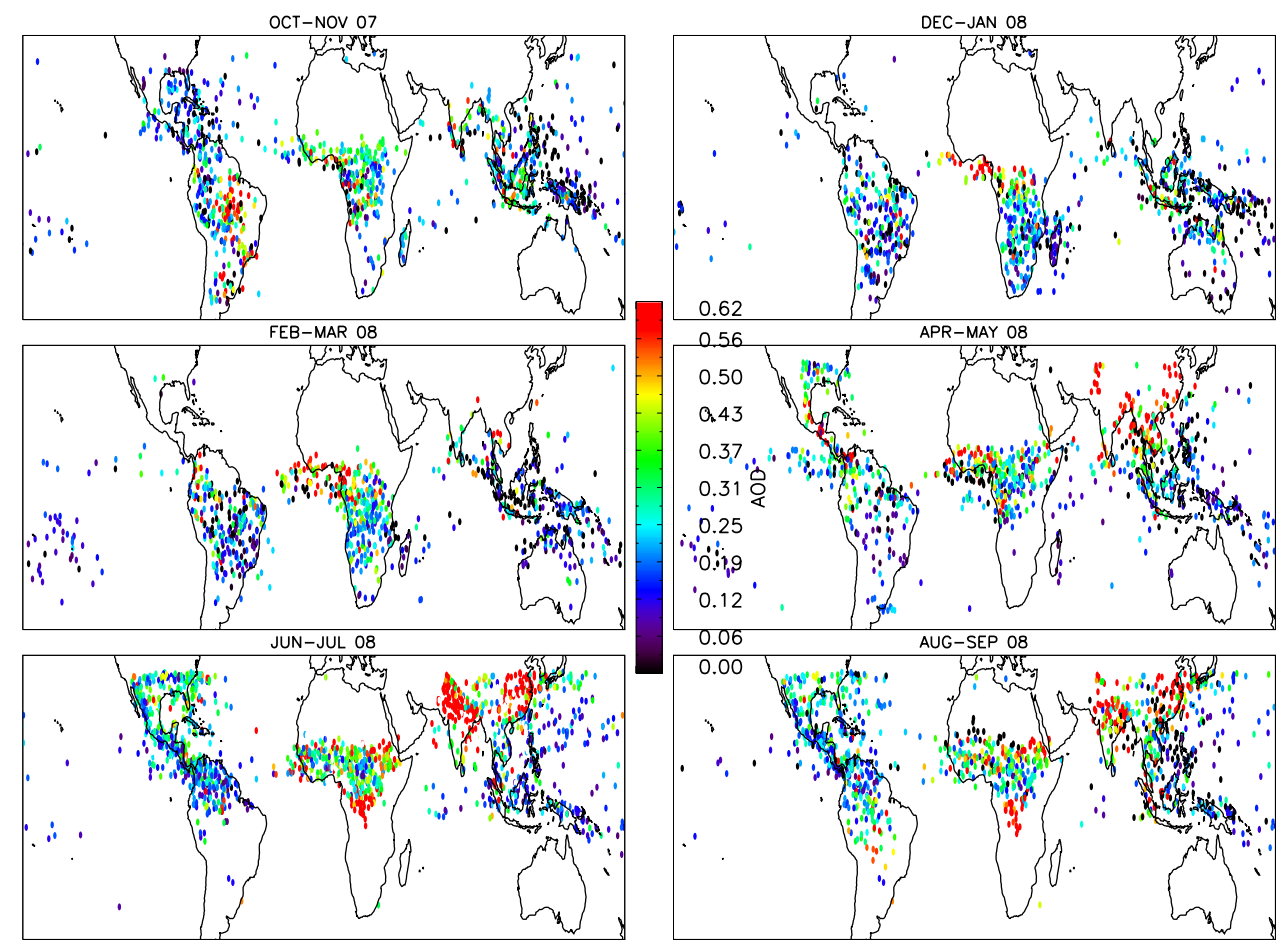

Fig. 6. Bimonthly maps from October 2007 to September 2008 of TRMM Mesoscale Convective Systems (MCS $>14 \mathrm{~km})$ tagged with MODIS Aerosol Optical Depth. The nearest AOD value of each MCS was extracted from MODIS AOD grids with a temporal and spatial resolution of 2 days and $3^{\circ}$ lon $\times 3^{\circ}$ lat. MCS that could not be tagged where no AOD value was available are in black. The AOD fields have been constructed using the MODIS Level 3 daily joint aerosol/water vapor/cloud product of the Terra space borne platform that cross the equator at 10:30 a.m. LT.

\section{Modulation of the aerosol loading in the TTL by deep convection}

As previously shown, the cleansing of the lower stratosphere is correlated with the southern tropics convective season, but if not anticorrelated with the Northern Hemisphere season. We evaluate the convective transport of low versus high aerosol loading of tropospheric air masses in the TTL by studying the geographical position of MCSs as seen by the TRMM radar relative to the amount of aerosols in the troposphere. Since deep convection is known to show a pronounced diurnal cycle of peak intensity in late afternoon (Liu and Zipser, 2005), we have used the Aerosol Optical Depth (AOD) from MODIS on the TERRA satellite platform at 10:30 a.m. LT. Figure 6 represents bimonthly maps from October 2007 to September 2008 of MCS locations reaching at least $14 \mathrm{~km}$ tagged with the nearest value of MODIS AOD in space and time. Since more than one day of observations is required to obtain a complete spatial coverage, two days mean AOD maps have been constructed with a spatial resolution of $3^{\circ}$ lon $\times 3^{\circ}$ lat from the MODIS level 3 daily joint aerosol/water vapor and cloud product. As shown by Liu and Zipser (2005), the maps indicate that deep convection is dominant over land during the local summer convective season. The statistics of tagged-AOD MCSs is given in Table 2 for the different maps of Fig. 6. In October-November, the maximum of potential aerosols lofting occurs over East Amazonia next to the arid N-E Brazil, where a maximum $\mathrm{CO}$ in the lower stratosphere was also reported by Schoeberl et al. (2006). In December-January 2008, the convective activity is greatest above the continents of the Southern Hemisphere, in South America, South Africa, Indonesia and northern Australia. MCS occurred in relative clean environment $(\mathrm{AOD}<0.4)$ $73 \%$ of the time except in Central Africa where convection coincides with the beginning of biomass burning season as shown by the number of fires associated with $\mathrm{CO}$ emission (http://earthobservatory.nasa.gov/GlobalMaps/view.php? $\mathrm{d} 1=$ MODAL2_M_AER_OD $\backslash \& \mathrm{~d} 2=$ MOD14A1_M_FIRE) During this period, the Harmattan wind from the north-east advects Saharan dust towards MCSs in Western Africa. Later in the winter season (February-March 2008), the ITCZ and land convection have moved northward but still remain in clean tropospheric conditions with $76 \%$ of MCS with AOD $<0.4$. In early spring, in April-May, the aerosol loading associated with convection increases (MCS of AOD $>0.4$ ) by $10 \%$ compared to previous periods. This polluted convection occurs primarily in Western and Central 
Table 2. Percentage (number) of Mesoscale Convective Systems (MCS) that was tagged with: AOD $<=0.2$ (column 1 ), $0.2<$ AOD $<0.4$ (column 2) and AOD > = 0.4 (column 3). The last column shows the percentage of events that could not be tagged.

\begin{tabular}{lrrrr}
\hline Period/AOD & AOD $<=0.2$ & $0.2<$ AOD $<0.4$ & AOD $>=0.4$ & NA \\
\hline Oct-Nov-07 & $34 \%(377 M C S)$ & $39(432)$ & $14(157)$ & $11(128)$ \\
Dec-Jan-08 & $34(362)$ & $42(445)$ & $9(98)$ & $12(134)$ \\
Feb-Mar-08 & $35(365)$ & $38(392)$ & $13(141)$ & $12(131)$ \\
Apr-May-08 & $31(333)$ & $36(383)$ & $21(226)$ & $10(111)$ \\
Jun-Jul-08 & $29(325)$ & $30(341)$ & $25(289)$ & $14(165)$ \\
Aug-Sep-08 & $31(354)$ & $33(371)$ & $24(276)$ & $10(121)$ \\
\hline
\end{tabular}

African regions of biomass burning and Saharan dust, but also in South East Asia when the monsoon onset is reaching the Bay of Bengal and Thailand. The highest level of aerosol associated with convection occurs during the $\mathrm{NH}$ summer (June-July 2008 and August-September 2008), where 25\% of MCSs are associated with AOD $>0.4$ and $65 \%$ of MCS tagged with extreme AOD values $(>0.6)$ are located over Southeast Asia (NE China and NW India). As shown by Dey et al. (2010), polluted aerosols with dust dominate the population of particles especially in northeast India and along the Indo-Ganges basin. Deep convection occurring over those regions could transport aerosols upwards, confirming the possible convective origin of an elevated layer observed during the Asian monsoon reported by Vernier et al. (2011a).

To better quantify the impact of convection on the TTL aerosol load, we have created an Aerosol Index (AI, Eq. 3) that is the average of the tagged MCS-AOD occurring within a 16-days period in a particular latitude band. It is given by

$$
\mathrm{AI}(t)=\frac{1}{N} \sum_{n=1, N} \operatorname{MCS}(n, t) \times \operatorname{AOD}(n, t),
$$

where $n$ is the index of each MCS ( $N$ the total) occurring in the time and space resolution as described below. The AI has been computed from TRMM and CloudSat MCSs extracted for the later one from the University of Utah database (http://trmm.chpc.utah.edu) by selecting convective events reaching $14 \mathrm{~km}$ of at least $500 \mathrm{~km}$ horizontal extension. Figure 7 shows a comparison between this index and the mean CALIOP SR between 14 and $17 \mathrm{~km}$. To emphasize the effect of deep convection on the TTL aerosols, we have calculated the mean CALIOP SR within the ITCZ from the 10th and 90th percentile CALIPSO cloudy pixels (latitude band within the white line in Fig. 5). Since volcanic plumes from Tavurvur and Sarychev contaminate the years of 2006 and 2009, respectively (Figs. 1, 2 and 5), we focus on the 2007-2008 period. The annual cycle of TTL aerosols from CALIPSO is well matched by the AI deep convection-AOD model without significant phase lag using TRMM as well as CloudSat. However, the strong summer time CALIPSO SR peak is not seen on the AI that rather shows a slight maximum expending from April to November.

The relationship between AI and CALIPSO SR is reasonable, indicating that air masses transported by deep convection from the relatively clean surfaces of the southern tropics (Congo, Amazonia and Indonesian Islands) may be indeed responsible for the cleansing of the TTL during the NH winter. The contrast between the convective cleansing observed in the South and the reinforcement of aerosols in the TTL in the North is consistent with the increased AI during the NH summer by convective lofting of natural and anthropogenic aerosols during the Asian and African monsoon seasons (Fig. 7).

However, the rapid cleansing of the TTL up to $19-20 \mathrm{~km}$ during the SH convective season shows significantly higher vertical propagation than of the aerosol enhancement in the $\mathrm{NH}$ convective season that is limited to $16-17 \mathrm{~km}$. This might be related to the influence of the aerosols on convection intensity. Rosenfeld et al. (2008) suggested that the vigorous convection as inferred from the Convective Available Potential Energy is maximum with AOD close to 0.25. This value is remarkably close to the lowest AI values reach (that represent also a mean AOD) in the Southern tropics during the $\mathrm{NH}$ winter when the cleansing is more intense, reaching as high as $19-20 \mathrm{~km}$.

\section{Impact of overshooting updrafts at the global scale}

The mass flux of tropospheric air required for explaining the cleansing of the TTL during the SH convective season was tentatively derived from the drop of aerosol observed during the period November 2007-February 2008 (Fig. 5). Figure 8 illustrates the conceptual model used to calculate the time constant of dilution and the total mass flux between the troposphere and the stratosphere corresponding to the updrafts. As detailed in Appendix A, a mass conservation flux is applied to the rectangle on the top of the anvil to estimate the amount of clean tropospheric air required at a level $z$ to cleanse up the lower stratosphere. Assuming a constant size distribution and similar composition for the aerosols populating the UTLS, the CALIOP (SR-1) $\left(\mathrm{SR}-1=\beta_{\mathrm{part}} / \beta_{\mathrm{mol}}\right) \mathrm{can}$ 
Table 3. Average mass flux in $10^{8} \mathrm{~kg} \mathrm{~s}^{-1}$ and time constant $(\tau)$ in month, required for a (SR-1) decrease by $63 \%$ in the TTL between $20^{\circ} \mathrm{S}-0^{\circ} \mathrm{S}$ between $15 \mathrm{~km}-20 \mathrm{~km}$. Values are derived from the overshoot dilution model (Appendix A) and compared to radiative heating calculations by Corti et al. (2005) on yearly average basis and by Yang et al. (2008) during the NH winter only.

\begin{tabular}{llll}
\hline Altitude & $\begin{array}{l}\text { Mass flux from CALIPSO } \\
\left(10^{8} \mathrm{~kg} \mathrm{~s}^{-1}\right)\end{array}$ & $\begin{array}{l}\text { From Corti } \\
\text { et al. (2005) }\end{array}$ & $\begin{array}{l}\text { From Yang } \\
\text { et al. (2008) }\end{array}$ \\
\hline $15 \mathrm{~km}$ & $780 \pm 390(\tau=1.5 \pm 0.5$ months) $)$ & 139 & \\
$16 \mathrm{~km}$ & $670 \pm 340(\tau=1.5 \pm 0.5)$ & 102 & 56 \\
$17 \mathrm{~km}$ & $430 \pm 160(\tau=2 \pm 0.5)$ & 65 & 74 \\
$18 \mathrm{~km}$ & $240 \pm 60(\tau=3 \pm 0.5)$ & 19 & 28 \\
$19 \mathrm{~km}$ & $200 \pm 50(\tau=3 \pm 0.5)$ & 9 & 9 \\
$20 \mathrm{~km}$ & $120 \pm 20(\tau=4 \pm 0.5)$ & 9 & 9 \\
\hline
\end{tabular}

be considered to be proportional to an aerosol mixing ratio. After applying the mass and aerosol mixing ratio flux conservation, the aerosol mixing ratio is shown to follow an e-folding law, where $t$, the time constant required for (SR1) to decrease by $63 \%$, is directly proportional to the mass flux. The time $t$ required for such reduction in CALIOP observations ranges from $1.5 \pm 0.5$ months at $15 \mathrm{~km}$, to $3 \pm 0.5$ months at $18 \mathrm{~km}$, and $4 \pm 0.5$ months at $20 \mathrm{~km}$ (Table 3 ). The fluxes corresponding to the cleansing of each layer at global scale shown in Table 3, are $780 \pm 390 \times 10^{8} \mathrm{~kg} \mathrm{~s}^{-1}$ at $15 \mathrm{~km}$ and $240 \pm 60 \times 10^{8} \mathrm{~kg} \mathrm{~s}^{-1}$ at $18 \mathrm{~km}$. Below $18 \mathrm{~km}$, they are 5 to 12 times larger than those derived from radiative heating calculations by Corti et al. (2005) and Yang et al. (2008). At the higher levels, at $18-20 \mathrm{~km}$, they are even larger (up 20 times), showing that convective overshooting could be a large contributor to the cleansing of the lower tropical stratosphere.

There are, however, some limitations in the validity of the method used in the above calculations. The conversion of the Scattering Ratio into an aerosol-mixing ratio required a constant phase function in time and altitude meaning that aerosol composition and size distribution remained the same. However, even if, as measured by Froyd et al. (2009) over Costa Rica, the aerosols above the tropopause are for $75 \%$ made of sulphate-organic particles, $20 \%$ of them were of carbonaceous material. Since organics particles are known to be more absorbing than scattering, this would imply that the phase function used in the conversion would not be conservative below the tropopause. In addition the calculation applies only if aerosols are long lifetime tracers, insensitive to changes by microphysical processes. But since sulfateorganic particles are dominants in the convective $\mathrm{SH}$ region and microphysical processes have little impact on these as discussed below, the above limitations are expected to have little impact on the conclusions.

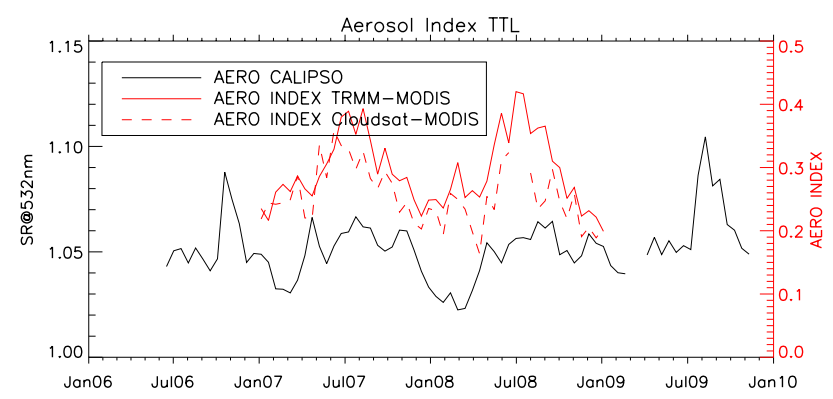

Fig. 7. CALIPSO mean SR between $14-17 \mathrm{~km}$ (black line) within the "ITCZ area" delimited by the 10th and 90th percentile of the CALIPSO cloudy pixel product derived from the depolarization (Fig. 5). The Aerosol Indices are derived from TRMM (red solid line) and CloudSat (dotted red line) MCSs located between $20^{\circ} \mathrm{N}-$ $20^{\circ} \mathrm{S}$.

\section{Discussion}

Although there is clear indication of the surface origin of the clean air and its transport in the lower stratosphere by convective updraft, other processes could potentially contribute for explaining them and the difference between the northern and Southern Hemispheres. They are briefly discussed below.

\subsection{Cleansing mechanisms}

Several mechanisms can be invoked which could potentially contribute to the cleansing of the aerosols in the TTL: (i) a decrease of the particles size by microphysical processes making them less efficient to scattering light; (ii) the capture of the aerosols by cirrus clouds followed by sedimentation; and (iii) a fast sedimentation of the particles.

\subsubsection{Particle size reduction}

A significant fraction of particles in the TTL seems to be composed of sulfate-organic mixing (Fryod et al., 2009). It 


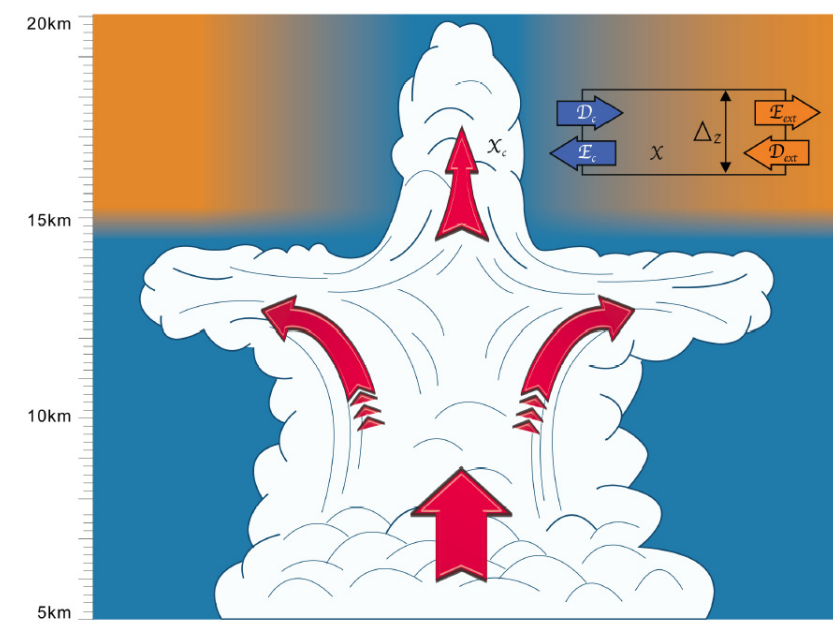

Fig. 8. Schematic of the TTL aerosol-cleansing model by overshooting towers.

has been shown by Steel and Hamill (1981) that sulfate particles can growth significantly in the presence of water vapor at low temperature and thus result in SR-1 enhancements. The amplitude of the effect depends on the initial concentration of the particles and the amount of nitric acid $\left(\mathrm{HNO}_{3}\right)$ available. Assuming an initial concentration of sulfate of 10 particles $\mathrm{cm}^{-3}$ and using water vapor, temperature and $\mathrm{HNO}_{3}$ observations from MLS/Aura, the Mie SR-1 increase was shown to not exceed $10 \%$ in the worst case, mainly because of the very low $\mathrm{HNO}_{3}$ concentration near the tropical tropopause. The change in retrieved aerosols profiles is not significant.

\subsubsection{Capture by cirrus clouds}

Another process could be the capture of aerosol particles in cirrus clouds. Indeed, if aerosols served as condensation nuclei for cirrus formation, they could be removed by the further sedimentation of cirrus ice crystals. However, as shown by high altitude aircraft sampling above Costa-Rica during the Pre-AVE campaign (Froyd et al., 2009), the aerosols above the tropopause associated to Amazonian convective systems are mainly sulfate-organic particles of $<0.1 \mu \mathrm{m}$ diameter resulting in very limited freezing (Froyd et al., 2010). However, this could be different in the Northern Hemisphere, since, in contrast, mineral dust and black carbon particles can act as efficient heterogeneous ice nuclei forming ice crystals (Froyd et al., 2010 and references therein). In conclusion, if such process contributes to the $16-17 \mathrm{~km}$ altitude limitation of the aerosols in Northern Hemisphere, it cannot explain the cleansing in the Southern Hemisphere during the convective season.

\subsubsection{Aerosol sedimentation}

Sulfate or sulfate-organic particles of $0.1-0.2 \mu \mathrm{m}$ radius, as observed in the tropical lower stratosphere by the optical particle counter over Northern Brazil (Fig. 3) or CostaRica (Froyd et al., 2010), are falling at a rate of less than $0.1 \mathrm{~km} \mathrm{month}^{-1}$ at $18 \mathrm{~km}$ altitude. About $\sim 40$ months would be required for them to drop from 18 to $14 \mathrm{~km}$, which is far too slow for explaining the cleansing. However, this is not true for larger mineral dust particles of $\sim 1 \mu$ m diameter above the Asian sector (Anderson et al., 2003), which will be falling by $1 \mathrm{~km} \mathrm{month}^{-1}$ at $18 \mathrm{~km}$, and thus could explain the limited altitude of the aerosols layer in the Northern Hemisphere during the monsoon season.

In conclusion, apart from the freezing and the sedimentation of large mineral dust particles which might explain the absence of aerosols enhancements above $17 \mathrm{~km}$ during the Northern Hemisphere summer, there is no indication that the above processes could contribute significantly to the cleansing of the lower stratosphere in the Southern Hemisphere.

\subsection{Vertical transport processes}

Aside from deep convective updraft, other potential contributing processes include slow ascent by radiative heating, vertical turbulent diffusivity and gravity waves. As already shown, the ascent by radiative heating at a rate of less than $0.4 \mathrm{~mm} \mathrm{~s}^{-1}$ or $1 \mathrm{~km} \mathrm{month}^{-1}$ (Yang et al., 2008) will require 6-9 months for an air mass to reach $20 \mathrm{~km}$ from the tropopause, that is far too slow for explaining the observations. It cannot contribute for more than $10 \%$ to the zonal mean flux. The same conclusion applies to the average vertical turbulent diffusivity of $0.02 \mathrm{~m}^{2} \mathrm{~s}^{-1}$ derived by Mote et al. (1998) from the total hydrogen profiles of the Halogen Occultation Experiment which would require about $5 \mathrm{yr}$ for a one kilometre rise. Even with the upper bound equivalent diffusivity of $0.5 \mathrm{~m}^{2} \mathrm{~s}^{-1}$ derived by Pisso and Legras (2008) from balloon ozone and water vapor profiles measurements during the HIBISCUS campaign in Brazil, thus including turbulent diffusivity and gravity waves, it would take 2.5 months for a one-kilometer uplift. The only remaining explanation is thus frequent injections of clean tropospheric air by convective overshooting that would progressively dilute the aerosols and clean the lower stratosphere. Since the overshooting frequency is known to decrease at increasing altitude (Liu and Zipser, 2005), the amplitude of dilution will also decrease with altitude, which is what is observed. This scheme is consistent with the observations of geyser-like injections of ice particles in the lower tropical stratosphere up to $19 \mathrm{~km}$ over land convective regions (Nielsen et al., 2007; Corti et al., 2008; Khaykin et al., 2009) implying a hydration process of the lower stratosphere, as well as the injection of adiabatically cooled air modifying its thermal structure (Pommereau et al., 2011). It would also be consistent with the larger $\mathrm{N}_{2} \mathrm{O}$, $\mathrm{CH}_{4}$ and $\mathrm{CO}$ concentrations in the lower stratosphere over 
tropical continents in contrast to oceans, as well as their seasonal variation reported by Ricaud et al. (2007, 2009) or Schoeberl et al. (2008). It will imply a top TTL, the region sharing tropospheric and stratospheric characteristics, around $20 \mathrm{~km}$, higher than generally assumed (Fueglistaler et al., 2008). Finally, it will result in the fast transport of chemically reactive Very Short-Lived Species (VSLS) in the lower stratosphere with their possible impact on ozone chemistry. However, if such deep overshooting events and the resulting hydration of the lower stratosphere are well captured by non-hydrostatic meso-scale cloud resolving model simulations (e.g. Chaboureau et al., 2007; Grosvenor et al., 2007; Jenssen et al., 2007), they are poorly, if at all, represented by global Chemistry Transport Models (CTM) forced by $\mathrm{Nu}$ merical Weather Forecast (NWP) Models, enable to reproduce the impact of such events at global scale.

\section{Conclusions}

The three-year CALIOP aerosols profiles in the tropics reveal the existence of a fast cleansing process of the lower stratosphere up to $20 \mathrm{~km}$. It is shown to take place in the Southern Hemisphere during the convective season, where overshooting systems seen by the TRMM precipitation radar are occurring in clean regions of the troposphere over African, SouthAmerican rain forests and the Indonesian islands, as shown by the minimum MODIS Aerosols Optical Depth over these areas.

Such cleansing would be consistent with repeated injections of relatively clean air by overshooting updrafts in the air masses circumnavigating within less than two months in the tropical lower stratosphere, resulting in the progressive dilution of aerosols present there. The tropospheric air flux by those events might be 5-20 times larger than that corresponding to the previously assumed slow ascent by radiative heating. The fast extension of the cleansing to the northern tropics and the southern sub-topical lower stratosphere during the same season is consistent with the advection of the clean air injected at this level in the ITCZ region by the upper branch the Hadley cell. In contrast to the cleansing during the Southern Hemisphere summer, the aerosol increase observed in the Northern Hemisphere during the convective season, consistent with the large MODIS AOD within $10^{\circ}-$ $40^{\circ} \mathrm{N}$ over South Asia, suggesting instead, an injection of desert mineral dust and soot from biomass burning, but limited to around $16-17 \mathrm{~km}$ probably because of their fast sedimentation at higher altitude. The CALIPSO aerosols observations suggest that convective overshooting might be a major contributor of troposphere-to-stratosphere transport, with the many implications on the TTL top height, hydration, photochemistry and thermal structure of the lower stratosphere, a mechanism well captured by non-hydrostatic meso-scale models but missed by global meteorological and climatic models.

\section{Appendix A}

\section{Overshoot updrafts mass flux}

As shown by the conceptual overshoot model in Fig. 8, the mass flux conservation in the TTL can be written:

$D_{\mathrm{c}}-E_{\mathrm{c}}+D_{\mathrm{ext}}-E_{\mathrm{ext}}=0$

where,

- $D_{\mathrm{c}}$ is the convective flow ( $D$ for Detrainment) (unit $\mathrm{kg} \mathrm{m}^{-1} \mathrm{~s}^{-1}$ )

- $E_{\mathrm{c}}$ is that extracted ( $E$ for Entrainment)

- $D_{\text {ext }}$ is the input from horizontal transport and

- $E_{\text {ext }}$ the horizontal outflow.

Neglecting the weak transport from mid-latitudes to the tropics allows simplifying Eq. (A1) in:

$D_{\mathrm{c}}-E=0 \quad$ (with $\left.E=E_{\mathrm{c}}-E_{\mathrm{ext}}\right)$

The change of aerosol mixing ratio, $\chi$, due to the mixing with clean air can be expressed:

$\rho \cdot A \cdot \frac{\partial \chi}{\partial t}=D_{\mathrm{c}} \cdot \chi_{\mathrm{c}}-E \cdot \chi$

where $\rho$ is the air density, $A$ the surface of the layer, and $\chi_{\mathrm{c}}$ the aerosol mixing ratio in the convective cloud. The solution of Eq. (A3) is:

$\chi(t)=\left(\chi_{0}-\chi_{\mathrm{c}}\right) e^{\frac{D_{\mathrm{c}}}{\rho A} \cdot t}+\chi_{\mathrm{c}}$

where $\chi_{0}$ is the initial aerosol mixing ratio in the layer and $\chi(t)$ its change following an e-folding law, with $\tau=\rho A / D_{\mathrm{c}}$ assuming that the aerosol-mixing ratio in the convective cloud is negligible (clean air, $\chi_{\mathrm{c}}=0$ ).

Since, $\tau$ is the time required for reducing the aerosol mixing ratio by $63 \%$, the inflow Fc within each $1 \mathrm{~km}$ thick layer between $15-20 \mathrm{~km}$ can be expressed:

$F_{\mathrm{c}}=D_{\mathrm{c}}^{\prime} \cdot \Delta Z=\frac{\Delta Z \rho A}{\tau}$

Assuming that the CALIPSO backscatter ratio $\left(\mathrm{SR}-1=\frac{\beta_{\text {mie }}}{\beta_{\text {ray }}}\right)$ is proportional to the aerosol mixing ratio. The tropospheric air flux required for cleansing the TTL can be derived from the decrease of CALIOP mean SR from November 2007 to February 2008 between $20^{\circ} \mathrm{S}-0^{\circ} \mathrm{S}$ shown in Fig. 5 using Eq. (A4). The resulting fluxes are displayed in Table 1.

Acknowledgements. This work was part of the $\mathrm{PhD}$ thesis of JPV financed by the Centre National la Recherche Scientifique at LATMOS/UVSQ in France now on a NASA Postdoctoral Program at Langley Research Center, administrated by Oak Ridge Associated Universities. The research was supported by the CNES CALIPSO and European SCOUT-O3 projects. 
The CALIOP data were made available at the ICARE data center (http://www-icare.univ-lille1.fr/) and processed at NASA LaRC. The authors want also to thank the University of Utah for providing the TRMM and CloudSat MCS searching system (http://trmm.chpc.utah.edu/). The author wants to thank Kristina Ruhlman for making the conceptual view of overshoot in Fig. 7, Jay Kar for the processing of the Aerosol Optical Depth data from the CALIPSO level 2 products and P. Lucker for her help in the processing of the CALIPSO level 1 data. Finally, we gratefully acknowledge L. Pool for his microphysical calculation on the size-dependence of sulfate particles according to the temperature, nitric acid and water vapor mixing ratio.

Edited by: T. J. Dunkerton

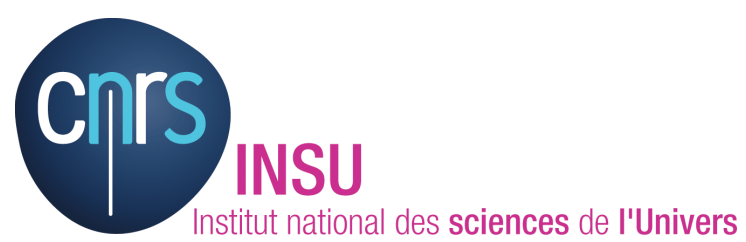

The publication of this article is financed by CNRS-INSU.

\section{References}

Anderson, T. L., Masonis, S. J., Covert, D. S., Ahlquist, N. C., Howell, S. G., Clarke, A. D., and McNaughton, C. S.: Variability of aerosol optical properties derived from in situ aircraft measurements during ACE-Asia, J. Geophys. Res., 108, 8647, doi:10.1029/2002JD003247, 2003.

Borchi, F. and Pommereau, J.-P.: Evaluation of ozonesondes, HALOE, SAGE II and III, Odin- OSIRIS and -SMR, and ENVISAT-GOMOS, -SCIAMACHY and -MIPAS ozone profiles in the tropics from SAOZ long duration balloon measurements in 2003 and 2004, Atmos. Chem. Phys., 7, 2671-2690, doi:10.5194/acp-7-2671-2007, 2007.

Bourassa, A. E., Degenstein, D. A., Elash, B. J., and Llewellyn, E. J.: Evolution of the stratospheric aerosol enhancement following the eruptions of Okmok and Kasatochi: OdinOSIRIS measurements, J. Geophys. Res., 115, D00L03, doi:10.1029/2009JD013274, 2010.

Borrmann, S., Kunkel, D., Weigel, R., Minikin, A., Deshler, T., Wilson, J. C., Curtius, J., Volk, C. M., Homan, C. D., Ulanovsky, A., Ravegnani, F., Viciani, S., Shur, G. N., Belyaev, G. V., Law, K. S., and Cairo, F.: Aerosols in the tropical and subtropical UT/LS: in-situ measurements of submicron particle abundance and volatility, Atmos. Chem. Phys., 10, 5573-5592, doi:10.5194/acp-10-5573-2010, 2010.

Brock, C. A., Hamill, P., Wilson, J. C., Jonsson, H. H., and Chan, K. R.: Particle formation in the upper tropical troposphere: A source of nuclei for the stratospheric aerosol, Science, 270, 1650-1653, 1995.

Brunner, D., Siegmund, P., May, P. T., Chappel, L., Schiller, C., Müller, R., Peter, T., Fueglistaler, S., MacKenzie, A. R., Fix, A., Schlager, H., Allen, G., Fjaeraa, A. M., Streibel, M., and Harris, N. R. P.: The SCOUT-O3 Darwin Aircraft Campaign: rationale and meteorology, Atmos. Chem. Phys., 9, 93-117, doi:10.5194/acp-9-93-2009, 2009.

Cairo, F., Pommereau, J. P., Law, K. S., Schlager, H., Garnier, A., Fierli, F., Ern, M., Streibel, M., Arabas, S., Borrmann, S., Berthelier, J. J., Blom, C., Christensen, T., D’Amato, F., Di Donfrancesco, G., Deshler, T., Diedhiou, A., Durry, G., Engelsen, O., Goutail, F., Harris, N. R. P., Kerstel, E. R. T., Khaykin, S., Konopka, P., Kylling, A., Larsen, N., Lebel, T., Liu, X., MacKenzie, A. R., Nielsen, J., Oulanowski, A., Parker, D. J., Pelon, J., Polcher, J., Pyle, J. A., Ravegnani, F., Rivière, E. D., Robinson, A. D., Röckmann, T., Schiller, C., Simões, F., Stefanutti, L., Stroh, F., Some, L., Siegmund, P., Sitnikov, N., Vernier, J. P., Volk, C. M., Voigt, C., von Hobe, M., Viciani, S., and Yushkov, V.: An introduction to the SCOUT-AMMA stratospheric aircraft, balloons and sondes campaign in West Africa, August 2006: rationale and roadmap, Atmos. Chem. Phys., 10, 2237-2256, doi:10.5194/acp-10-2237-2010, 2010.

Chaboureau, J.-P., Cammas, J.-P., Duron, J., Mascart, P. J., Sitnikov, N. M., and Voessing, H.-J.: A numerical study of tropical crosstropopause transport by convective overshoots, Atmos. Chem. Phys., 7, 1731-1740, doi:10.5194/acp-7-1731-2007, 2007.

Chen, P.: Isentropic cross-tropopause mass exchange in the extratropics, J. Geophys. Res., 100, 16661-16674, doi:10.1029/95JD01264, 1995.

Corti, T., Luo, B. P., Peter, P., Vömel, H., and Fu, Q.: Mean radiative energy balance and vertical mass fluxes in the equatorial upper troposphere and lower stratosphere, Geophys. Res. Lett., 32, L06802, doi:10.1029/2004GL021889, 2005.

Corti, T., Luo, B. P., de Reus, M., Brunner, D., Cairo, F., Mahoney, M. J., Martucci, G., Matthey, R., Mitev, V., dos Santos, F. H., Schiller, C., Shur, G., Sitnikov, N. M., Spelten, N., Vossing, H. J., Borrmann, S., and Peter, T.: Unprecedented evidence for overshooting convection hydrating the tropical stratosphere, Geophys. Res. Lett., 35, L10810, doi:10.1029/2008GL033641, 2008.

Danielsen, E. F.: A dehydration mechanism for the stratosphere, Geophys. Res. Lett., 9, 605-608, 1982.

Danielsen, E. F.: In situ evidence of rapid, vertical, irreversible transport of lower tropospheric air into the lower stratosphere by convective cloud turrets and by large scale up welling in tropical cyclones, J. Geophys. Res., 98, 8665-8681, 1993.

Deshler, T., Hervig, M. E., Hofmann, D. J., Rosen, J. M., and Liley, J. B.: Thirty years of in situ stratospheric aerosol size distribution measurements from Laramie, Wyoming (41N), using balloon-borne instruments, J. Geophys. Res., 108, 4167, doi:10.1029/2002JD002514, 2003.

Dey, S. and Di Girolamo, L.: A climatology of aerosol optical and microphysical properties over the Indian subcontinent from 9 years (2000-2008) of Multiangle Imaging Spectroradiometer (MISR) data, J. Geophys. Res., 115, D15204, doi:10.1029/2009JD013395, 2010.

Dunkerton, T.: Evidence of meridional motion in the summer lower stratosphere adjacent to monsoon regions, J. Geophys. Res., 100, 16675-16688, 1995.

Froyd, K. D., Murphy, D. M., Sanford, T. J., Thomson, D. S., Wilson, J. C., Pfister, L., and Lait, L.: Aerosol composition of the tropical upper troposphere, Atmos. Chem. Phys., 9, 4363-4385, doi:10.5194/acp-9-4363-2009, 2009.

Froyd, K. D., Murphy, D. M., Lawson, P., Baumgardner, D., 
and Herman, R. L.: Aerosols that form subvisible cirrus at the tropical tropopause, Atmos. Chem. Phys., 10, 209-218, doi:10.5194/acp-10-209-2010, 2010.

Fu, R., Hu, Y., Wright, J. S., Jiang, J. H., Dickinson, R. E., Chen, M., Filipiak, M., Read, W. G., Waters, J. W., and $\mathrm{Wu}$, D. L.: Short circuit of water vapor and polluted air to the global stratosphere by convective transport over the Tibetan Plateau, P. Natl. Acad. Sci. USA, 103, 5664-5669, doi:10.1073/pnas.0601584103, 2006.

Fueglistaler, S., Dessler, A. E, Dunkerton, T. J., Folkins, I., Fu, Q., and Mote, P. W.: The tropical tropopause layer, Rev. Geophys., 47, RG1004, doi:10.1029/2008RG000267, 2008.

Gettelman, A. and de Forster, P. M.: A climatology of the Tropical Tropopause Layer, J. Met. Soc. Japan, 80, 911-924, 2002.

Gettelman, A., Kinnison, D. E., Dunkerton, T. J., and Brasseur, G. P.: Impact of monsoon circulations on the upper troposphere and lower stratosphere, J. Geophys. Res., 109, D22101, doi:10.1029/2004JD004878, 2004.

Grosvenor, D. P., Choularton, T. W., Coe, H., and Held, G.: A study of the effect of overshooting deep convection on the water content of the TTL and lower stratosphere from Cloud Resolving Model simulations, Atmos. Chem. Phys., 7, 4977-5002, doi:10.5194/acp-7-4977-2007, 2007.

Hamill, P., Jensen, E. J., Russell, P. B., and Bauman, J. J.: The life cycle of stratospheric aerosol particles, B. Am. Meteorol. Soc., 78, 1395-1410, 1997.

Holton, J. R., Haynes, P. H., McIntyre, M. E., Douglass, A. R., Rood, R. B., and Pfister, L.: Stratosphere-troposphere exchange, Rev. Geophys., 33, 403-439, 1995.

Hostetler, C. A., Liu, Z., Regan, J., Vaughan, M., Winker, D., Osborn, M., Hunt, W. H., Powell, K. A., and Trepte, C.: Caliop Algorithm Theoretical Basis Document (ATBD), Calibration and Level 1 Data Products, available at: https://www.calipso.larc. nasa.gov/resources/pdfs/PC-SCI-201v1.0.pdf, 2006.

Hunt, W. H., Winker, D. M., Vaughan, M. A., Powell, K. A., Lucker, P. L., and Weimer, C.: CALIPSO Lidar Description and Performance Assessment, J. Atmos. Oceanic Technol., 26, 1214-1228, 2009.

Jensen, E. J., Ackerman, A. S., and Smith J. A.: Can overshooting convection dehydrate the tropical tropopause layer?, J. Geophys. Res., 112, D11209, doi:10.1029/2006JD007943, 2007.

Khaykin, S., Pommereau, J.-P., Korshunov, L., Yushkov, V., Nielsen, J., Larsen, N., Christensen, T., Garnier, A., Lukyanov, A., and Williams, E.: Hydration of the lower stratosphere by ice crystal geysers over land convective systems, Atmos. Chem. Phys., 9, 2275-2287, doi:10.5194/acp-9-2275-2009, 2009.

Liu, C. and Zipser, E. J.: Global distribution of convection penetrating the tropical tropopause, J. Geophys. Res., 110, D23104, doi:10.1029/2005JD006063, 2005.

Liu, C. and Zipser, E. J.: Implications of the day versus night differences of water vapor, carbon monoxide, and thin cloud observations near the tropical tropopause, J. Geophys. Res., 114, D09303, doi:10.1029/2008JD011524, 2009.

McCormick, M. P., Thomason, L. W., and Trepte, C. R.: Atmospheric effects of the Mt. Pinatubo eruption, Nature, 373, 399404, doi:10.1038/373399a0, 1995.

Mote, P. W., Rosenlof, K. H., McIntyre, M. E., Carr, E. S., Gille, J. C., Holton, J. R., Kinnersley, J. S., Pumphrey, H. C., Russell, J. M., and Waters, J. W.: An atmospheric tape recorder: The im- print of tropical tropopause temperatures on stratospheric water vapor, J. Geophys. Res., 101, 3989-4006, 1996.

Mote, P. W., Dunkerton, T. J., McIntyre, M. E., Ray, E. A., Haynes, P. H., Russel, III J. M.: Vertical velocity, vertical diffusion and dilution by midlatitude air in the tropical lower stratosphere, J. Geophys. Res., 103, 8651-8666, 1998.

Nielsen, J. K., Larsen, N., Cairo, F., Di Donfrancesco, G., Rosen, J. M., Durry, G., Held, G., and Pommereau, J. P.: Solid particles in the tropical lowest stratosphere, Atmos. Chem. Phys., 7, 685695, doi:10.5194/acp-7-685-2007, 2007.

Pisso, I. and Legras, B.: Turbulent vertical diffusivity in the sub-tropical stratosphere, Atmos. Chem. Phys., 8, 697-707, doi:10.5194/acp-8-697-2008, 2008.

Plumb, R.: A "tropical pipe" model of stratospheric transport, J. Geophys. Res., 101, 3957-3972, 1996.

Pommereau, J.-P., Garnier, A., Held, G., Gomes, A. M., Goutail, F., Durry, G., Borchi, F., Hauchecorne, A., Montoux, N., Cocquerez, P., Letrenne, G., Vial, F., Hertzog, A., Legras, B., Pisso, I., Pyle, J. A., Harris, N. R. P., Jones, R. L., Robinson, A. D., Hansford, G., Eden, L., Gardiner, T., Swann, N., Knudsen, B., Larsen, N., Nielsen, J. K., Christensen, T., Cairo, F., Fierli, F., Pirre, M., Marécal, V., Huret, N., Rivière, E. D., Coe, H., Grosvenor, D., Edvarsen, K., Di Donfrancesco, G., Ricaud, P., Berthelier, J.-J., Godefroy, M., Seran, E., Longo, K., and Freitas, S.: An overview of the HIBISCUS campaign, Atmos. Chem. Phys., 11, 2309-2339, doi:10.5194/acp-11-2309-2011, 2011.

Randel, W. J., Park, M., Emmons, L., Kinnison, D., Bernath, P., Walker, K. A., Boone, C., and Pumphrey, H.: Asian Monsoon Transport of Pollution to the Stratosphere, Science, 328, 611613, doi:10.1126/science.1182274, 2010.

Ricaud, P., Barret, B., Attié, J.-L., Motte, E., Le Flochmoën, E., Teyssèdre, H., Peuch, V.-H., Livesey, N., Lambert, A., and Pommereau, J.-P.: Impact of land convection on tropospherestratosphere exchange in the tropics, Atmos. Chem. Phys., 7, 5639-5657, doi:10.5194/acp-7-5639-2007, 2007.

Ricaud, P., Pommereau, J.-P., Attié, J.-L., Le Flochmoën, E., El Amraoui, L., Teyssèdre, H., Peuch, V.-H., Feng, W., and Chipperfield, M. P.: Equatorial transport as diagnosed from nitrous oxide variability, Atmos. Chem. Phys., 9, 8173-8188, doi:10.5194/acp-9-8173-2009, 2009.

Rosen, J. M. and Kjome, N. T.: The Backscattersonde: a new instrument for atmospheric aerosol research, Appl. Opt., 30, 15521561, 1991.

Rosenfeld, D., Lohmann, U., Raga, G. B., O’Dowd, C. D., Kulmala, M., Fuzzi, S., Reissell, A., and Andreae, M. O.: Flood or Drought: How Do Aerosols Affect Precipitation?, Science, 321, 1309-1313, 2008.

Rosenlof, K. H.: Seasonal cycle of the residual mean meridional circulation in the stratosphere, J. Geophys. Res., 100, 5173-5191, 1995.

Sassen, K., Wang, Z., and Liu, D.: Cirrus clouds and deep convection in the tropics: Insights from CALIPSO and CloudSat, J. Geophys. Res., 114, D00H06, doi:10.1029/2009JD011916, 2009.

Schoeberl, M. R., Duncan, B. N., Douglass, A. R., Waters, J., Livesey, N., Read, W., and Filipiak, M.: The carbon monoxide tape recorder, Geophys. Res. Lett., 33, 12811, doi:10.1029/2006GL026178, 2006.

Schwartz, M. J., Lambert, A., Manney, G. L., Read, W. G., Livesey, 
N. J., Froidevaux, L., Ao, C. O., Bernath, P. F., Boone, C. D., Cofield, R. E., Daffer,W. H., Drouin, B. J., Fetzer, E. J., Fuller, R. A., Jarnot, R. F., Jiang, J. H., Jiang, Y. B., Knosp, B. W., Kruger, K., Li, J.-L. T., Mlynczak, M. G., Pawson, S.,Russell III, J. M., Santee, M. L., Snyder, W. V., Stek, P. C., Thurstans, R. P., Tompkins, A. M., Wagner, P. A., Walker, K. A., Waters, J. W., and Wu, D. L.: Validation of the Aura Microwave Limb Sounder temperature and geopotential height measurements, J. Geophys. Res., 113, D15S11, doi:10.1029/2007JD008783, 2008.

Spackman, J. R., Gao, R., Schwarz, J., Watts, L., Fahey, D., Pfister, L., and Bui, T. P.: Seasonal variability of black carbon mass in the tropical tropopause layer, Geophys. Res. Lett., 38, L09803, doi:10.1029/2010GL046343, 2011.

Steele, H. M. and Hamill, P.: Effects of temperature and humidity on the growth and optical properties of sulfuric acid-water droplets in the stratosphere, J. Atmos. Sci., 12, 517-523, 1981.

Thomason, L. W., Burton, S. P., Luo, B.-P., and Peter, T.: SAGE II measurements of stratospheric aerosol properties at non-volcanic levels, Atmos. Chem. Phys., 8, 983-995, doi:10.5194/acp-8-9832008, 2008.

Trepte, C. R., Vaughan, M., Kato, S., and Young, S.: The Dispersal of Smoke in the UTLS Region Following the Australian PyroCB Event of February 2009 as Observed by CALIPSO, AGU Fall Meeting, San-Francisco, December 2009.

Vernier, J. P., Pommereau, J. P., Garnier, A., Pelon, J., Larsen, N., Nielsen, J., Christensen, T., Cairo, F., Thomason, L. W., Leblanc, T., and McDermid, I. S.: The tropical stratospheric aerosol layer from CALIPSO lidar observations, J. Geophys. Res., 114, D00H10, doi:10.1029/2009JD011946, 2009.
Vernier, J.-P., Thomason, L. W., and Kar, J.: CALIPSO detection of an Asian tropopause aerosol layer, Geophys. Res. Lett., 38, L07804, doi:10.1029/2010GL046614, 2011a.

Vernier, J. P., Thomason, L. W., Pommereau, J. P., Bourassa, A., Pelon, J., Garnier, A., Hauchecorne, A., Blanot, L., Trepte, C., Degenstein, D., and Vargas, F.: Major influence of tropical volcanic eruptions on the stratospheric aerosol layer during the last decade, Geophys. Res. Lett., 38, L12807, doi:10.1029/2011GL047563, 2011b.

Winker, D. M., Pelon, J., Coakley Jr., J. A., Ackerman, S. A., Charlson, R. J., Colarco, P. R., Flamant, P., Fu, Q., Hoff, R., Kittaka, C., Kubar, T. L., LeTreut, H., McCormick, M. P., Megie, G., Poole, L., Powell, K., Trepte, C., Vaughan, M. A., and Wielicki, B. A.: The CALIPSO Mission: A Global 3D View Of Aerosols And Clouds, B. Am. Meteorol. Soc., 91, 1211-1229, doi:10.1175/2010BAMS3009.1, 2010.

Yang, Q., Fu, Q., Austin, J., Gettelman, A., Li, F., and Vömel, H.: Observationally derived and general circulation model simulated tropical stratospheric upward mass fluxes, J. Geophys. Res., 113, D00B07, doi:10.1029/2008JD009945, 2008.

Zipser, E. J., Cecil, D., Liu, C., Nesbitt, S., and Yorty, D.: Where are the most intense thunderstorms on earth?, B. Am. Meteorol. Soc., 87, 1057-1071, 2006. 